\title{
Cell Preparation Tube
}

National Cancer Institute

\section{Source}

National Cancer Institute. Cell Preparation Tube. NCI Thesaurus. Code C153166.

An evacuated blood collection tube that contains sodium heparin, intended for the

collection of whole blood and the separation of mononuclear cells. 